\title{
Implementasi Algoritma Apriori Dalam Menganalisis Pola Penjualan Pada Restoran Sederhana
}

\author{
Randi Abizal*, Yohani Syahra**, Hafizah** \\ * Sistem Informasi, STMIK Triguna Dharma, Medan \\ ** Sistem Informasi, STMIK Triguna Dharma Medan
}

\begin{tabular}{l}
\hline \hline Article Info \\
\hline Article history: \\
Received Jan $02^{\text {th }}, 2022$ \\
Revised Jan $15^{\text {th }}, 2022$ \\
Accepted Jan $27^{\text {th }}, 2022$
\end{tabular}

\section{Keyword:}

Apriori

Data Mining

Menu Makanan

Pola Penjualan

Restoran Sederhana

\begin{abstract}
Restoran Sederhana adalah perusahaan waralaba Indonesia yang bergerak di bidang jasa boga atau makanan dengan ciri khas masakan Padang, juga memiliki hidangan khusus, yakni Ayam Pop yang telah dikenal luas. Pihak manajemen Restoran Sederhana terkadang sering mengalami kendala dalam memenuhi pemesanan makanan yang ada dan terkendala dengan bahan baku. Oleh sebab itu Pihak manajemen Restoran Sederhana dituntut untuk mencari solusi dalam pengelolaan kebutuhan bahan baku makanan dan menemukan strategi yang dapat meningkatkan usaha dibidang penjualan terutama harus meningkatkan pelayanan terbaik. Salah satu strategi yang dapat dilakukan adalah harus meningkatkan pelayanan terbaik dan mencari asosiasi dari menu makanan yang tersedia dengan cara mengikuti pola pembelian yang sering dilakukan pelanggan tersebut untuk mempermudah pengambilan keputusan persediaan bahan baku makanan. Untuk mengatasi permasalahan tersebut salah satu cara adalah menggunakan teknik analisis keranjang belanja atau Market Basket Analysis (MBA) yaitu analisis dari kebiasaan membeli konsumen dengan algoritma Apriori. Metode Apriori ini merupakan suatu cara mengukur data kedekatan antar menu makanan yang disediakan Hasil akhirnya adalah suatu aplikasi Data Mining yang dapat digunakan untuk untuk mengetahui pola penjualan menu makanan yang ada pada Restoran Sederhana dan untuk mengetahui manajemen bahan baku pembuatan menu makanan.
\end{abstract}

Copyright $(2022$ STMIK Triguna Dharma. All rights reserved.

\author{
Corresponding Author:* \\ Nama: Randi Abizal \\ Program Studi: Sistem Informasi \\ Afiliasi: STMIK Triguna Dharma \\ Email: randiabizal369@gmail.com
}

\section{PENDAHULUAN}

Penjualan merupakan salah satu kegiatan pemasaran yang cukup penting dalam rangka pencapaian tujuan perusahaan. Penjualan adalah ilmu dan seni mempengaruhi pribadi yang dilakukan oleh penjual untuk mengajak orang lain agar bersedia membeli barang yang ditawarkan. Pencapaian tingkat penjualan perusahaan adalah salah satu indikator dari tingkat kemajuan perusahaan, untuk mampu mencapai tingkat penjualan yang telah ditargetkan perusahaan itu berarti perusahaan harus mampu menciptakan produk dan jasa yang sesuai dengan kebutuhan dan keinginan konsumen juga bagaimana produk ini menjadi sumber profit bagi perusahaan sebagai fokus perusahaan dalam memasarkan produknya [1].

Restoran Sederhana adalah perusahaan waralaba Indonesia yang bergerak di bidang jasa boga atau makanan dengan ciri khas masakan Padang, dimana berawal pada tahun 1972 dari sebuah rumah makan Padang kecil milik Bustaman di Pasar Bendungan Hilir, Jakarta. Dalam mengelola restorannya, Bustaman yang berasal dari Lintau, Sumatra Barat, selalu menyesuaikannya dengan lidah orang kebanyakan, sehingga ia mengurangi rasa pedas dalam masakan Padang buatannya. Ia juga memiliki hidangan khusus, yakni Ayam Pop yang telah dikenal luas. Pihak manajemen Restoran Sederhana terkadang sering mengalami kendala dalam memenuhi pemesanan makanan yang ada dan terkendala dengan bahan baku. 
Oleh sebab itu Pihak manajemen Restoran Sederhanadituntut untuk mencari solusi dalam pengelolaan kebutuhan bahan baku makanan dan menemukan strategi yang dapat meningkatkan usaha dibidang penjualan terutama harus meningkatkan pelayanan terbaik. Salah satu strategi yang dapat dilakukan adalahharus meningkatkan pelayanan terbaik. Salah satu strategi yang dapat dilakukan adalahmencari asosiasi dari menu makanan yang tersedia dengan cara mengikuti pola pembelian yang sering dilakukan pelanggan tersebutguna untuk mempermudah pengambilan keputusan persediaan bahan baku makanan yang ada di Restoran Sederhana. Dalam masalah yang dibahas dalam penelitian ini akan dirancang sebuah perangkat lunak berbasis Dekstop Programming yang diharapkan dapat menjadi solusi pemecahan.

Teknik yang dapat digunakan untuk mengetahui pola penjualan makanan secara online di Restoran Sederhana adalah teknik asosiasi, dimana teknik ini dapat mengolah data untuk mengetahui keterkaitan antar menu makanan yang dipesan. Maka dari itu teknik yang akan digunakan pada penelitian ini adalah asosiasi dengan menggunakan algoritma Apriori.

Data Mining merupakan bidang ilmu yang mengajarkan tentang pengolahan data-data yang besar dengan tujuan untuk mencari informasi yang bermanfaat dari data tersebut sehingga data yang menumpuk itu dapat bermanfaat. Data mining adalah proses mencari pola atau informasi menarik dalam data terpilih dengan menggunakan teknik atau metode tertentu. Teknik-teknik, metode-metode, atau algoritma dalam data mining sangat bervariasi. Pemilihan metode atau algoritma yang tepat sangat bergantung pada tujuan dan proses Knowledge Discovery in Database (KDD) secara keseluruhan [2].

Data mining adalah suatu kegiatan analisa data untuk mencari suatu pola tertentu, dengan jumlah data yang besar dan bertujuan utuk menghasilkan informasi yang dapat digunakan dan dikembangkan lebih lanjut sehingga dapat membantu dalam pengambilan keputusan [3]. Pengelompokan teknik Data Mining dibagi menjadi 6 bagian yaitu : (1) Deskripsi, (2) Estimasi, (3) Prediksi, (4) Klasifikasi, (5) Pengklasteran, (6) Asosiasi [4].

Metode Apriori ini merupakan suatu cara mengukur data kedekatan antar produk makanan yang disediakan. Apriori adalah metode yang sering memanfaatkan itemset dalam pertambangan data atau produk [5]. Algoritma Apriori adalah salah satu algoritma yang melakukan pencarian frequent itemset dengan menggunakan teknik association rule. Algoritma apriori adalah suatu metode untuk mencari pola hubungan antar satu atau lebih item dalam suatu dataset [6].

Penelitian dengan menggunakan algoritma apriori, diantaranya untuk mendapatkan pola rekomendasi belanja produk pada toko avis mobile [7]. Menentukan pola ketersediaan stok barang berdasarkan permintaan konsumen di chykes minimarket [8].

\section{METODE PENELITIAN}

\subsection{Teknik Pengumpulan Data}

Metode penelitian adalah suatu cara ilmiah untuk mendapatkan data yang valid dengan tujuan dapat ditemukan, dikembangkan, atau dibuktikan suatu pengetahuan tertentu sehingga pada gilirannya dapat digunakan untuk memahami, memecahkan, dan mengantisipasi masalah dalam bidang tertentu.

Teknik pengumpulan data berupa suatu pernyataan tentang sifat, keadaan, kegiatan tertentu dan sejenisnya.Pengumpulan data dalam penelitian ini dilakukan di Restoran Sederhana yang berkaitan dengan penjualan menu makanan menggunakan 2 cara berikut merupakan uraian yang digunakan. Dalam tekhnik pengumpulan data terdapat beberapa yang dilakukan diantaranya yaitu:

1 Observasi

Metode pengumpulan data ini digunakan untuk mendapatkan data yang berkaitan dengan peninjauan langsung ke Restoran Sederhana maupun terhadap konsumen/tamu dan melakukan survey mengenai menu yang sering dibeli oleh konsumen.

2 Wawancara

Pengumpulan data dengan melakukan tanya jawab langsung dengan narasumber dari objek yang diteliti untuk memperoleh yang diinginkan. Wawancara dilakukan guna mendapatkan alur kerja pada objek yang diteliti yang akan digunakan dalam menentukan fitur-fitur yang akan dibangun. Pada tahapan wawancara dilakukan dengan cara mewawancarai Admin maupun Manager di Restoran Sederhana tentang penjualan menu makanan. 


\subsection{Algoritma Apriori}

Metodologi dasar analisis asosiasi terbagi menjadi dua yaitu :

Tahap ini mencari kombinasi item yang memenuhi syarat minimum dari nilai support dalam database. Nilai support sebuah item diperoleh dengan rumus berikut [9].

Support $A=\frac{\text { jumlah } \mathrm{T} \text { ransaksi }(\mathrm{A} \text { ) }}{\text { Transaksi }} \times 100 \%$

Sedangkan nilai support dari dua item diperoleh dari rumus berikut:

Support $A, B=P A \rightarrow \mathrm{B}=\quad \frac{\text { jumlah } T \text { ransahsi } A \rightarrow \mathrm{B}}{\text { Transahsi }} \times 100 \%$

Setelah semua pola frekuensi tinggi ditemukan, barulah dicari aturan asosiatif yang memenuhi syarat minimum untuk confidence dengan menghitung confidence aturan asosiatif $\mathrm{A} \rightarrow \mathrm{B}$.

Nilai confidence dari aturan $\mathrm{A} \rightarrow \mathrm{B}$ diperoleh dari rumus berikut :

Confidence $A, B=P A \rightarrow \mathrm{B}=\quad \frac{\text { Jwmiah } \mathrm{T} \text { ransaksi } A \rightarrow \mathrm{B}}{\text { Trangaki }} \times 100 \%$

Aturan asosiasi biasanya dinyatakan dalam bentuk:

$\{$ roti, mentega $\} \rightarrow\{$ susu $\}$ (support $=40 \%$, confidence $=50 \%$ )

Aturan tersebut berarti : " $50 \%$ dari transaksi di database yang memuat item roti dan mentega juga memuat item susu. Sedangkan $40 \%$ dari seluruh transaksi yang ada di database memuat ketiga item itu. Dapat juga diartikan: "Seorang konsumen yang membeli roti dan mentega punya kemungkinan 50\% untuk juga membeli susu. Aturan ini cukup signifikan karena mewakili 40\% dari catatan transaksi selama ini."

Analisis asosiasi didefinisikan suatu proses untuk menemukan semua aturan assosiatif yang memenuhi syarat minimum untuk support (minimum support) dan syarat minimum untuk confidence (minimum confidence). Penting tidaknya suatu aturan asosiatif dapat diketahui dengan dua parameter, yaitu support dan confidence. Support (nilai penunjang) adalah presentase kombinasi item tersebut dalam database, sedangkan confidence nilai kepastian) adalah kuatnya hubungan anta item dalam aturan asosiasi [10].

\section{ANALISA DAN HASIL}

\subsection{Penerapan Algoritma Apriori}

Dalam tahap ini akan dilakukan uji coba terhadap aplikasi Data Mining dengan menggunakan Algoritma Apriori yang telah dibangun.

Pada tahapan wawancara dilakukan dengan cara mewawancarai Admin maupun Manager di Restoran Sederhana tentang penjualan menu makanan, sesuai dengan tabel 1 berikut.

Tabel 1. Daftar Menu Makanan

\begin{tabular}{lll}
\hline No & \multicolumn{2}{c}{ Kode } \\
& Transaksi & \\
\hline 1 & TR01 & Ikan Kakap Sambal, Nasi Bungkus Paru Goreng \\
2 & TR02 & Nasi Bungkus Gulai Kikil, Martabak Spesial \\
3 & TR03 & Ikan Kakap Sambal, Nasi Bungkus Telur Dadar, Nasi Bungkus Teri Petai \\
4 & TR04 & Gembung Rica, Nasi Bungkus Gulai Kikil \\
5 & TR05 & Nasi Bungkus Gulai Kikil, Gembung Rica \\
6 & TR06 & Nasi Bungkus Telur Dadar, Gembung Rica, Nasi Bungkus Gulai Kikil \\
7 & TR07 & Nasi Bungkus Kentang Telur Puyuh, Gembung Rica, Roti Cane Coklat Keju \\
8 & TR08 & Ayam Rendang, Nasi Bungkus Dendeng Batokok, Nasi Bungkus, Gulai Kikil \\
9 & TR09 & Nasi Bungkus Dendeng Batokok, Gembung Rica \\
10 & TR10 & Nasi Bungkus Gulai Otak, Nasi Bungkus Dendeng Batokok \\
\hline
\end{tabular}

J-SISKO TECH Vol. 5, No. 1, Januari 2022 : 76-82 


\begin{tabular}{|c|c|c|}
\hline 11 & TR11 & $\begin{array}{l}\text { Nasi Bungkus Gulai Otak, Nasi Bungkus Rendang Daging, Nasi } \\
\text { Bungkus Gulai Kikil }\end{array}$ \\
\hline 12 & TR12 & $\begin{array}{l}\text { Nasi Bungkus Teri Petai, Nasi Bungkus Rendang Daging, Nasi } \\
\text { Bungkus Telur Dadar, Ikan Kakap Sambal }\end{array}$ \\
\hline 13 & TR13 & $\begin{array}{l}\text { Nasi Bungkus Teri Petai, Nasi Bungkus Rendang Daging, Nasi } \\
\text { Bungkus Telur Dadar, Ikan Kakap Sambal }\end{array}$ \\
\hline 14 & TR14 & $\begin{array}{l}\text { Nasi Bungkus Telur Dadar, Gembung Bakar, Nasi Bungkus } \\
\text { Rendang Daging, Ikan Kakap Sambal }\end{array}$ \\
\hline 15 & TR15 & $\begin{array}{l}\text { Nasi Bungkus Rendang Daging, Nasi Bungkus Telur Dadar, Gembung Rica, } \\
\text { Ikan Kakap Sambal, Ayam Goreng Panas }\end{array}$ \\
\hline 16 & TR16 & Nasi Bungkus Dendeng Batokok, Gembung Bakar, Ikan Kakap Sambal \\
\hline
\end{tabular}

Pada hasil pengujian dapat dilihat pada tabel 2 dimana hasil yang didapat adalah sebagai berikut.

Tabel 2. Hasil Apriori

\begin{tabular}{|c|c|c|c|c|c|}
\hline No & Item & & Frekuensi & Support & Confidence \\
\hline 1 & $\begin{array}{l}\text { Nasi Bungkus } \\
\text { Rendang Daging }\end{array}$ & $\begin{array}{l}\text { Ikan Kakap } \\
\text { Sambal }\end{array}$ & 10 & 16.95 & 76.92 \\
\hline 2 & $\begin{array}{l}\text { Nasi Bungkus } \\
\text { Rendang Daging }\end{array}$ & $\begin{array}{l}\text { Nasi Bungkus } \\
\text { Dendeng Batokok }\end{array}$ & 6 & 10.17 & 54.55 \\
\hline 3 & $\begin{array}{l}\text { Nasi Bungkus } \\
\text { Rendang Daging }\end{array}$ & Gembung Rica & 5 & 8.47 & 50.00 \\
\hline 4 & $\begin{array}{l}\text { Nasi Bungkus } \\
\text { Rendang Daging }\end{array}$ & $\begin{array}{l}\text { Nasi Bungkus } \\
\text { Gulai Otak }\end{array}$ & 6 & 10.17 & 60.00 \\
\hline 5 & $\begin{array}{l}\text { Nasi Bungkus } \\
\text { Rendang Daging }\end{array}$ & $\begin{array}{l}\text { Nasi Bungkus } \\
\text { Gulai Otak }\end{array}$ & 6 & 10.17 & 60.00 \\
\hline 6 & $\begin{array}{l}\text { Nasi Bungkus } \\
\text { Rendang Daging }\end{array}$ & $\begin{array}{l}\text { Nasi Bungkus } \\
\text { Teri Petai }\end{array}$ & 7 & 11.86 & 87.50 \\
\hline 7 & $\begin{array}{l}\text { Nasi Bungkus } \\
\text { Rendang Daging }\end{array}$ & $\begin{array}{l}\text { Nasi Bungkus } \\
\text { Teri Petai }\end{array}$ & 7 & 11.86 & 87.50 \\
\hline 8 & $\begin{array}{l}\text { Nasi Bungkus } \\
\text { Rendang Daging }\end{array}$ & $\begin{array}{l}\text { Ayam Goreng } \\
\text { Panas }\end{array}$ & 6 & 10.17 & 100.00 \\
\hline 9 & $\begin{array}{l}\text { Nasi Bungkus } \\
\text { Rendang Daging }\end{array}$ & $\begin{array}{l}\text { Nasi Bungkus } \\
\text { Telur Dadar }\end{array}$ & 4 & 6.78 & 66.67 \\
\hline 10 & Ikan Kakap Sambal & $\begin{array}{l}\text { Nasi Bungkus } \\
\text { Teri Petai }\end{array}$ & 4 & 6.78 & 50.00 \\
\hline 11 & Ikan Kakap Sambal & $\begin{array}{l}\text { Nasi Bungkus } \\
\text { Teri Petai }\end{array}$ & 4 & 6.78 & 50.00 \\
\hline 12 & Ikan Kakap Sambal & $\begin{array}{l}\text { Ayam Goreng } \\
\text { Panas }\end{array}$ & 3 & 5.08 & 50.00 \\
\hline 13 & Ikan Kakap Sambal & $\begin{array}{l}\text { Nasi Bungkus } \\
\text { Telur Dadar }\end{array}$ & 5 & 8.47 & 83.33 \\
\hline 14 & $\begin{array}{l}\text { Nasi Bungkus Teri } \\
\text { petai }\end{array}$ & $\begin{array}{l}\text { Nasi Bungkus Teri } \\
\text { Petai }\end{array}$ & 8 & 13.56 & 100.00 \\
\hline 15 & $\begin{array}{l}\text { Nasi Bungkus Teri } \\
\text { Petai }\end{array}$ & $\begin{array}{l}\text { Nasi Bungkus } \\
\text { Telur Dadar }\end{array}$ & 3 & 5.08 & 50.00 \\
\hline 16 & $\begin{array}{l}\text { Nasi Bungkus Teri } \\
\text { Petai }\end{array}$ & $\begin{array}{l}\text { Nasi Bungkus } \\
\text { Telur Dadar }\end{array}$ & 3 & 5.08 & 50.00 \\
\hline
\end{tabular}




\subsection{Implementasi Sistem}

1. Form Hasil Perhitungan

Berikut gambar 1 merupakan hasil perhitungan dengan menggunakan Algoritma Apriori.

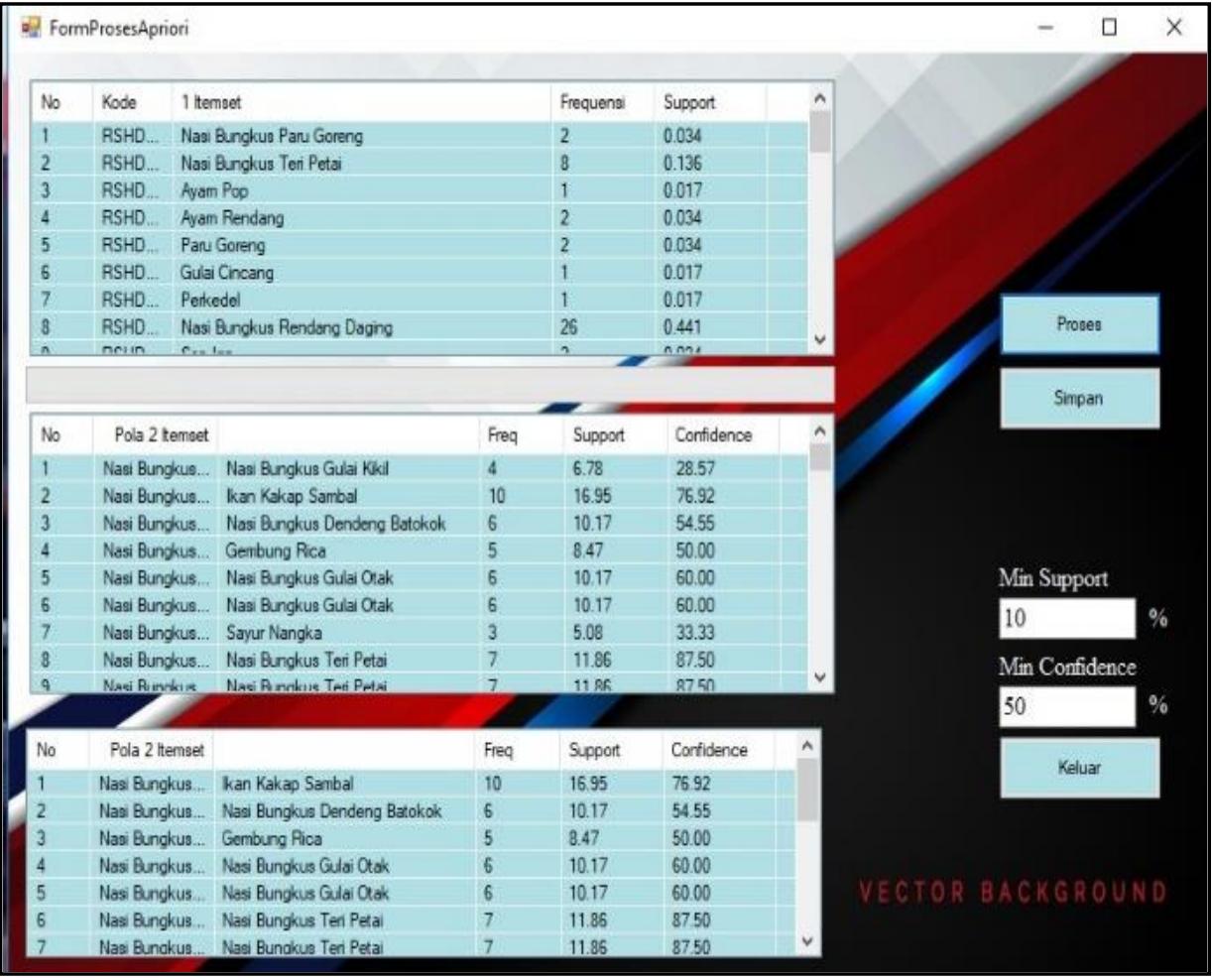

Gambar 1. Hasil Pengujian

2. Form Laporan

Berikut gambar 2 merupakan hasil perhitungan dalam bentuk laporan dengan menerapkan Algoritma Apriori.

\begin{tabular}{|c|c|c|c|c|c|}
\hline & \multicolumn{5}{|c|}{ 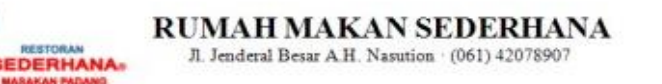 } \\
\hline \multicolumn{6}{|c|}{ Data Pola Penjualan Menu Makanan } \\
\hline № & Rule & & Frok & Suppost & Sentidences \\
\hline 1 & Nasi Bungkus Rendamy & |ikan Kakap Samteal & 10 & 16.95 & 76.92 \\
\hline 2 & Nasi Bungkus Rendan! & on Nasi Bungkus Denden! & 6 & 10.17 & 54.55 \\
\hline 3 & Nasi Bungkus Rendanf & Gembung Rica & 5 & 8.47 & 50.00 \\
\hline 4 & Nasi Bungkus Rendany & Nasi Bungkus Gulai Ot & 6 & 10.17 & 60.00 \\
\hline 5 & Nasi Bungkus Rendany & of Nasi Bungkus Gulai ot & 6 & 10.17 & 60.00 \\
\hline 6 & Nasi Bungkius Rendany & Nasi Bungkus Ton Petti & 7 & 11.86 & 87.50 \\
\hline 7 & Nasi Bungkus Rendany & Nasi Bungkus Ten Peti & 7 & 11.86 & 87.50 \\
\hline 8 & Nasi Bungkus Rendany & Ayam Goreng Panas & 5 & 10.17 & 100.00 \\
\hline 9 & Nassi Bungkus Rendarny & Nasi Bungkus Telur Da & 4 & 6.78 & 66.67 \\
\hline 10 & |ikan Kakap Sambal & Nasi Bungkus Teri Pett: & 4 & 678 & 5000 \\
\hline
\end{tabular}

Gambar 2. Hasil Laporan

J-SISKO TECH Vol. 5, No. 1, Januari 2022: 76-82 


\section{KESIMPULAN}

Berdasarkan analisa pada permasalahan yang terjadi dalam kasus yang diangkat tentang menentukan analisis terhadap pola penjualan menu makanan pada Restoran Sederhana, maka dapat ditarik kesimpulan sebagai berikut :

1. Cara menerapkan ilmu Data Mining dengan metode Apriori dapat dilakukan dengan mengolah data penjualan menu makanan, dimana setiap data transaksi akan diolah dengan cara mencari support dan confidence menghitung pola penjualan berdasarkan item setnya.

2. Tingkat support dan confidence dianalisa dari data penjualan menu makanan dan diatur minimum support dan confidence sehingga dapat menghasilkan data asosiasi yang nantinya digunakan untuk mengelola stok bahan mentah untuk olahan menu makanan di Restoran Sederhana.

3. Dalam merancang dan membangun aplikasi dengan menggunakan algoritma Apriori menggunakan aplikasi berbasis Desktop, yang pertama kali dilakukan adalah membuat solusi dari permasalahan dalam pencarian pola penjualan yang ada pada Restoran Sederhana kemudian melakukan perancangan untuk aplikasi desktop dengan menggunakan konsep UML, selanjutnya melakukan pengkodean pada Visual Studio, sehingga terciptalah aplikasi yang mampu menentukan pola penjualan dengan cepat berdasarkan data transaksi yang ada.

\section{UCAPAN TERIMA KASIH}

Terimakasih diucapkan kepada Ibu Yohanni Syahra dan Ibu Hafizah yang telah mendukung dalam proses penyelesaian penelitian ini. Kiranya bisa memberi manfaat bagi pembaca dan dapat meningkatkan kualitas penelitian selanjutnya.

\section{REFERENSI}

[1] R. Gusrizaldi, E. Komalasari, M. Dan, D. Program e S. Administrasi, "Analisis Faktor-Faktor Yang Mempengaruhi Tingkat Penjualan Di Indrako Swalayan Teluk Kuantan,” vol. 2, nº 2, pp. 286-303, 2016.

[2] A. H. Nasyuha et al., "Frequent pattern growth algorithm for maximizing display items," Telkomnika (Telecommunication Comput. Electron. Control., vol. 19, no. 2, pp. 390-396, 2021, doi: 10.12928/TELKOMNIKA.v19i2.16192.

[3] J. Hutagalung and F. Sonata, "Penerapan Metode K-Means Untuk Menganalisis Minat Nasabah Asuransi," vol. 5, no. 3, pp. 1187-1194, 2021, doi: 10.30865/mib.v5i3.3113.

[4] J. Hutagalung, N. L. W. S. R. Ginantra, G. W. Bhawika, W. G. S. Parwita, A. Wanto, and P. D. Panjaitan, "COVID-19 Cases and Deaths in Southeast Asia Clustering using K-Means Algorithm," J. Phys. Conf. Ser., vol. 1783, no. 1, 2021, doi: 10.1088/1742-6596/1783/1/012027.

[5] I. P. Astuti, "Algoritma Apriori Untuk Menemukan Hubungan Antara Jurusan Sekolah Dengan Tingkat Kelulusan Mahasiswa," Jurnal Teknik Informatika, vol. 12, no. 1, 2019.

[6] M. Syahril, K. Erwansyah, M. Yetri, "Penerapan Data Mining Untuk Menentukan Pola Penjualan Peralatan Sekolah Pada Brand Wigglo Dengan Menggunakan Algoritma Apriori”, J-Sisko Tech,” vol. 3, no. 1, pp. 118-136, 2020.

[7] K. Erwansyah, B. Andika, and R. Gunawan, "Implementasi Data Mining Menggunakan Asosiasi Dengan Algoritma Apriori Untuk Mendapatkan Pola Rekomendasi Belanja Produk Pada Toko Avis Mobile," J-SISKO TECH (Jurnal Teknol. Sist. Inf. dan Sist. Komput. TGD), vol. 4, no. 1, p. 148, 2021, doi: 10.53513/jsk.v4i1.2628.

[8] I. F. P. Ginting, D. Saripurna, and E. Fitriani, "Penerapan Data Mining Dalam Menentukan Pola Ketersediaan Stok Barang Berdasarkan Permintaan Konsumen Di Chykes Minimarket Menggunakan Algoritma Apriori," $J$. SAINTIKOM (Jurnal Sains Manaj. Inform. dan Komputer), vol. 20, no. 1, p. 28, 2021, doi: 10.53513/jis.v20i1.2504.

[9] H. Kusumo, "Analisis Algoritma Apriori Untuk Mendukung Strategi Promosi Perguruan Tinggi," Walisongo Journal of Information Technology, vol. 1, no 1, 2019.

[10] K. Erwansyah And T. Syahputra, "Penerapan Data Mining Untuk Mendapatkan Paket Promo," Journal of Science and Social Research, Vol. 4307, No. June, Pp. 96-105, 2021. 


\section{BIOGRAFI PENULIS}

\begin{tabular}{|l|l|}
\hline & $\begin{array}{l}\text { Nama : Randi abizal } \\
\text { Program Studi : Sistem Informasi } \\
\text { Tempat/Tgl Lahir : Sidodadi ,03-06-1999 } \\
\text { Hobi : Bermain futsal } \\
\text { Email : randiabizal369@ gmail.com }\end{array}$ \\
\hline & $\begin{array}{l}\text { Nama : Yohanni Syahra, S.Si., M.Kom } \\
\text { Program Studi : Sistem Informasi } \\
\text { Bidang Keilmuan : Data Mining dan Sistem Pakar } \\
\text { Email : yohanni.syahra@gmail.com }\end{array}$ \\
\hline & $\begin{array}{l}\text { Nama : Hafizah.S.Kom.,M.Kom } \\
\text { Program studi : Sistem Informasi } \\
\text { Bidang keilmuan: APSI dan JST } \\
\text { Email: hafizah22isnartiilyas@ @mail.com }\end{array}$ \\
\hline
\end{tabular}

J-SISKO TECH Vol. 5, No. 1, Januari 2022: 76-82 